\title{
Sustainable Forest Management Beyond the Timber-Oriented Status Quo: Transitioning to Co-production of Timber and Non-wood Forest Products—a Global Perspective
}

\author{
Jonathan P. Sheppard ${ }^{1}$ (D) James Chamberlain ${ }^{2}$ (D) - Dolores Agúndez ${ }^{3,4}$ (D) $\cdot$ Prodyut Bhattacharya ${ }^{5}$ (D) \\ Paxie Wanangwa Chirwa ${ }^{6}$ (D) - Andrey Gontcharov ${ }^{7}$ (D) - Willie Cliffie John Sagona ${ }^{8} \cdot$ Hai-long Shen $^{9}$ (D) \\ Wubalem Tadesse ${ }^{10} \cdot$ Sven Mutke ${ }^{3,4}$ (D)
}

Published online: 13 January 2020

(C) The Author(s) 2020

\begin{abstract}
Purpose of Review This review provides perspectives and insights of forest researchers from four continents representing a range of geo-regions, with examples from diverse and dynamic use of forest products that are undervalued and often misrepresented. A comprehensive discussion of the subject provides special attention to property, tenancy, public goods and access rights to nonwood forest products (NWFP), seen as forest ecosystem services in a framework for forest management decisions. The overall purpose is to provide a logical argument for transitioning to sustainable management of forests for timber and NWFP.

Recent Findings Multifunctional ecosystem-based approaches are transforming our understanding of forests. The prevailing economic relevance of NWFP for trade and sustenance requires their operative integration into forest management. Integration of NWFP will shift a traditional timber-oriented management paradigm towards an inclusive ecosystem forest management approach. We show that the impact of NWFP resources on livelihoods provides multiple benefits to all sectors of global society. Policy and property rights affect the availability and sustainability of the resource, while regulations, restrictions and prohibitions target the sustainable harvest of NWFP under growing demand. Official reporting of production volumes of NWFP is sparse, erratic or inaccurate due to a complex system that is opaque and with inadequately understood value chains, yet research is underway to better understand all NWFP sectors.

Summary A shift from command-and-control forest management to broader governance schemes is observed, yet despite a growing awareness of their importance, NWFP and their potential for a bio-based economy require more research. A conceptual framework for transitioning to sustainable co-production management of timber and NWFP is presented. Such a transition is needed to ensure long-term forest security, health and resilience.
\end{abstract}

Keywords Bio-based economy $\cdot$ Co-production $\cdot$ Food security $\cdot$ Forest-based value chains $\cdot$ Forest governance $\cdot$ Policy Sustainable forest management

Jonathan P. Sheppard

jonathan.sheppard@iww.uni-freiburg.de

James Chamberlain

james.1.chamberlain@usda.gov

Dolores Agúndez

agundez@inia.es

Prodyut Bhattacharya

prodyutbhattacharya@yahoo.com

Paxie Wanangwa Chirwa

Paxie.Chirwa@up.ac.za

\author{
Andrey Gontcharov \\ gontcharov@biosoil.ru \\ Willie Cliffie John Sagona \\ willsagona@gmail.com \\ Hai-long Shen \\ shenhl-cf@nefu.edu.cn \\ Wubalem Tadesse \\ wubalem16@gmail.com \\ Sven Mutke \\ mutke@inia.es
}

Extended author information available on the last page of the article 


\section{Introduction}

Throughout history, forests have provided human society with goods, essential for sustenance and income generation. Long before the technology existed to cut timber, humans were foraging forests for food, medicine and other basic necessities. In many developing countries today, nearly $20 \%$ of rural households derive income from forests and trees, as cash, or for subsistence needs for food and nutritional diversity [1]. Several hundred million people in the world live in or near forests and depend on them for sustenance or livelihood [2, 3]. Since the 1992 Rio Summit [4], increased awareness has led to formulation of conceptual frameworks that recognise essential provisioning, regulating and cultural services provided by forests and other ecosystems to humans, that integrate politics and economics, and what many cultures regard as cultural or spiritual values of forests [5, 6]. Forests are increasingly recognised for their contributions to access of food security and providing sources of raw materials and income and job creation from the sale of products from the plants, fungi and animals living within forests [7].

Plants and fungi harvested, in total or in part, for products other than timber are referred to by many terms: secondary, minor, specialty or special forest products; forest botanicals; non-wood forest products (NWFP); non-timber forest products (NTFP); or some semblance to these descriptors [8-10]. The United Nations Food and Agriculture Organization (FAO) defines Non-Wood Forest Products as "products of biological origin other than wood derived from forests, other wooded land and trees outside forests" [11]. The similar applicable concept of Non-Timber Forest Products is broader and includes some wood products that do not require timbersized trees, such as decorations (e.g. Christmas trees, branches), arts and crafts (e.g. canes, carvings), as well as firewood and charcoal [12]. NWFP also include animals and animal-based products such as wild meat or honey, while forest grazing or browsing is often essential for feeding domestic livestock $[11,13]$. For this review, we use the term NWFP, unless it does not provide appropriate context.

Many NWFP are harvested from natural populations (i.e. populations that are not managed or cultivated) in forests that are managed for other products, and are rarely explicit objectives in forest management plans, actions or policies. NWFP may be promoted as species for collection from forests or as cultivated species, within an agroforestry system (Table 1). NWFP are harvested for myriad purposes, including food, medicine, arts and crafts and cultural purposes $[12,14]$. Collection of edible forest products can be further classified into four flexible categories: (i) famine foods, (ii) foods to vary and supplement the diet, (iii) foods to sell and (iv) fodder for livestock which may provide food or income for a family $[15,16]$. Many indigenous fruits are the sources of important nutrients for human populations, especially in rural communities [17-20]. Functionally, classifying NWFP by the degree of domestication is useful (cf. $[21,22]$ see also Table 1); however, divisions between groups are fluid and overlaps occur frequently.

In extractive NWFP economies, excessive demand or lack of supply often result in classic boom-and-bust cycles, which can be mitigated by domestication and cultivation of the particular species. Innovation may stimulate cultivation of wildcollected species: oaks (Quercus spp.) nursery-inoculated with truffles (Tuber melanosporum Vittad), birches (Betula spp.) inoculated with the parasitic chaga or pakuri conk (Inonotus obliquus (Ach. Ex Pers.) Pilát), stone pine (Pinus pinea L.) grafted for Mediterranean pine nuts [25] and American ginseng (Panax quinquefolius L.) cultivated under shade structures since the mid-1800s [26]. The promotion and utilisation of NWFP commodities supports the concept of a future based on the utilisation of sustainably sourced natural resources as a foundation of a bio-based economy replacing the current modern fossil-based economy (cf. [27]). Around the world, the cultivation and management of NWFP provides the potential for stability to supply and demand, yet more research and development leading to innovation and a transitioning to sustainable co-production management is needed. This review provides perspectives and insights of forest researchers from four continents (Europe, North America (USA), Eastern Asia (Russian Far East, People's Republic of China, India) and Sub-Saharan Africa (SSA)) representing a range of geo-regions, where production, collection and exploitation of NWFP are diverse and have varied emphasis for local populations.

\section{Global Market Economic Context}

The forest sectors of most regions have largely focused on production of wood-based industrial scale products, because of the importance of wood and established markets [28]. In recent years, many regions have experienced an emergence or promotion of NWFP markets. In Europe, markets for resins, tannins, pine nuts, wild mushrooms and other niche NWFP [29] are developing rapidly. Similarly, markets for NWFP from China produced from tea seed oil (Camellia oleifera C.Abel), Chinese chestnut (Castanea mollissima Blume), Persian walnut (Juglans regia L.), Eucommia (Eucommia ulmoides Oliv.) or purpleblow maple (Acer truncatum Bunge) [30] are expanding. A recent national assessment of NTFP in the USA highlights the market demand and economic importance of NWFP to local and national economies [14]. Even though these examples illustrate a growing industry, the actual values of the NWFP forest sector remain largely enigmatic.

Estimates of the macroeconomic values of NWFP vary across the globe, indicating a need for regular and standardised measurement of volumes harvested and traded, 
Table 1 NWFP derivation from wild, promoted and cultivated sources

\begin{tabular}{|c|c|c|}
\hline Wild resources $\rightarrow$ & $\leftarrow$ Promoted resources $\rightarrow$ & $\leftarrow$ Cultivated resources \\
\hline $\begin{array}{l}\text { Spontaneous resources that are opportunistically } \\
\text { collected from wild and natural populations. } \\
\text { Harvesting (e.g. wild herbs, berries, nuts or } \\
\text { fungi) may be compatible with timber-oriented } \\
\text { forest management. Norms and skills, often } \\
\text { linked to local, traditional or indigenous } \\
\text { knowledge, are required for sustainable } \\
\text { collection. In many cases, collected products } \\
\text { are ephemeral or seasonal, and perishable if not } \\
\text { harvested in time. }\end{array}$ & $\begin{array}{l}\text { Biological resources actively encouraged in } \\
\text { forests, requiring co-production silvicultural } \\
\text { practices, stimulation techniques or external } \\
\text { inputs (e.g. beekeeping, sap, resin or gum } \\
\text { tapping, coppicing for wicker basketry or } \\
\text { forest grazing, browsing and mast feeding of } \\
\text { livestock/game) to sustain production. } \\
\text { Production requires specific skills set from } \\
\text { practitioners, often based on traditional } \\
\text { knowledge, occasionally on science-based } \\
\text { forest management. }\end{array}$ & $\begin{array}{l}\text { Cultivated resources, as agroforestry systems [23, } \\
\text { 24] or in plantations. Even if planted on } \\
\text { cropland, they can be included in the FAO [11] } \\
\text { definition of NWFP as "from trees outside } \\
\text { forests". There is no clear-cut boundary } \\
\text { between farming and forestry, but the transition } \\
\text { to forest farming combines NWFP grown } \\
\text { under trees for subsistence and income. }\end{array}$ \\
\hline
\end{tabular}

and prices paid along the value chains. Global estimates are sporadic, inconsistent and dated; in 1995, the estimated world trade in NWFP was in the order of US\$11 billion [31]. Few studies have attempted to update this estimate due to the inherent complexity of NWFP accounting [32]. To reinforce this point, the FAO [33] reported the annual global income generated from the production of NWFP in 2011, to be as high as US $\$ 88$ billion (this huge increase was essentially due to the inclusion of coco palm products [34]), and later suggested this figure was a vast underestimation of the real value [1]. Discrepancies in estimates of global economic values of NWFP highlight the importance of developing ways to improve NWFP accounting, reporting and estimation of these values.

In Europe, official estimates of the mean annual marketed NWFP are significant, but not completely consistent; the estimated annual values vary more than threefold, between US\$2.6 billion and US\$8.7 billion (cf. [29, 33]). The estimates of comprehensive market values of products traded in the formal economy are lacking due to limited reporting of actual volumes. The volumes and values of a few products that are recognised for their economic values are reported and estimated. Portugal reports revenues of US\$245 million annually from cork harvesting, largely as there are official figures due to an established production and processing industry central to its economy [35]. For many products, global prices are increasing for NWFP commodities at a greater rate than production volumes [36]. Likewise, quantification of local trade is extremely difficult because of its sporadic nature, and the large amount of trade without recorded transactions [37]. Frequently, much of the NWFP trade is in the informal economy with little or no records. Landowners show greater reliance on NWFP production, especially in regions, such as the Mediterranean, where forests present low timber growth rates and profitability with immense diversity of high-value NWFP (e.g. cork, mushrooms, truffles or pine nuts) [28]. Examples from other regions support this premise.
The commercial harvest of NWFP in the USA has contributed to household, state, regional and national economies for more than 250 years [14]. Citizens continue to forage food, medicine and other essentials for sustenance and income. Every year, commercial NWFP harvests contribute more than a US\$1 billion to the wholesale economy of the USA [38]. During the years 2009-2013, people received permits to harvest more than 3.5 million litres and 1300 million $\mathrm{kg}$ of edible forest products from federal public forests [38]. Because of their economic and ecological contributions, specific NWFP, such as American ginseng (US\$27 million) and maple syrup (US\$100 million), and market segments such as that for floral decoratives (US\$75 million) contribute significantly annually to regional economies [39-41].

Likewise, in the former Soviet Union, NWFP played notable roles in local and regional economies, with a welldeveloped network of about 18,000 state and cooperative factorias (trading posts) servicing the NWFP industry. These market players collected, and purchased from harvesters, undertook primary processing, and provided storage and transportation of NWFP through the distribution chain. With the fall of the Soviet Union, the market structure and dynamics changed rapidly and significantly [42]. Today, in Russia and the Far Eastern Federal District (FEFD) in particular, people harvest most berry species for local consumption, and for sale to primary private buyers. Often, products are traded unprocessed with little added value. The current market structure for many products is informal with no records, and therefore, challenging to evaluate actual quantity harvested and sold on the market, and the role in livelihood provision.

Across the FEFD, people collect annually approximately 90,200 tonnes of NWFP worth about US\$55 million, most of which is exported [43]. This estimate may be low as it represents only $15 \%$ of the potential amount. Pine nuts (Pinus koraiensis Siebold \& Zucc.) may be the highest valued NWFP in the FEFD. Unfortunately, due to poor forest management $[44,45]$, the once sustainable harvesting activity [46, $47]$ is in decline [48-50]. 
In China, the estimated value of NWFP, including fruits and nuts, woody oil, tea, ingredients for traditional Chinese medicine and forest foods, in 2010, was about US\$73 billion. The Chinese NWFP industry contributes more than $50 \%$ of total household income in many rural areas [51]. Farmers are planting NWFP on their land, and private enterprises and farmers' cooperatives are eager to rent land to grow NWFP on a large scale [51].

A final example, commercial NWFP collection in India, was estimated to generate nearly US $\$ 1.6$ billion, at the forest gate in 2010 [52]. By some estimates, the sale of NWFP attributed over $50 \%$ of all revenue earned by the Forest Department [53]. While nearly 400 million people living in and around forests depend on NWFP for sustenance and supplemental income, about $70 \%$ of the NWFP collection takes place in the tribal belt [54]. In many rural forest-dependent communities across India, NWFP provide half of the cash income for $30 \%$ of rural people [3]. In addition, India has a monopoly in world trade for some NWFP such as karaya gum (Sterculia urens Roxb.), myrobalans (Phyllanthus emblica L., Terminalia chebula Retz) and sandalwood (Santalum album) chips and dust.

Although much NWFP consumption is domestic, international trade is significant. According to Iqbal [31], more than $60 \%$ of global NWFP production is imported by countries of the European Union, the USA and Japan. For example, the EU-28 is responsible for $37 \%$ of global bamboo trade worth approximately US\$790 million and $80 \%$ of the global gum Arabic trade originating in Sudan, Chad, Nigeria and Mali worth approximately US\$140 million [55]. This reflects the general direction of trade from developing to developed countries, with China as a dominant world trader, and India, Indonesia, Malaysia, Thailand and Brazil as major suppliers to world markets. By some perspectives, NWFP trade has been negatively impacted due to unfriendly trade policies and regional politics; this may be most evident in SSA. Nonetheless, international trade is an important factor in the NWFP industry. Whereas international NWFP trade is an important generator of foreign currency, domestic NWFP consumption directly supports the livelihood, health and wellbeing of millions of people.

In many countries, international NWFP markets are complex and risky, because often NWFP that gain international demand are subject to competition from synthetic substitutes or cultivated products [56]. NWFP also are sensitive to consumer preferences and quality considerations, making their markets unpredictable and uncertain [57]. An increase in economic well-being and a shift to a monetary economy have, arguably, eroded NWFP local trade and barter systems, and their traditional uses in preference to factory-made products [37]. Under these circumstances, national and international markets greatly influence the range of products demanded and the marketing approaches applied.

\section{Global Non-market Economic Context}

A comprehensive assessment of NWFP collection and utilisation is challenging and complex, as much of the consumption happens at the household level, or through other non-market transactions. The total amount of NWFP harvest and usage is most likely significantly greater than what is reported [58]; therefore, non-market valuation techniques must be applied retrospectively to provide an estimate of the quantity and the value of the product harvested [14]. As evidence, an estimated $60 \%$ of NWFP harvests in India are unrecorded, as they are consumed directly or bartered by people living in and around the forest. A recent comparative analysis of nearly 8000 households in 24 developing countries showed that income from products gathered from natural forests accounted for $20 \%$ of total household income [59]. A recent review by Wiersum et al. [60] neatly summarised the position of NWFP in Europe where between 2012 and 2016 three large-scale surveys were conducted at a regional level [61-63]. The greatest finding was that between the EU-28 member states, an average of $25 \%$ of surveyed households (14,864 responses) directly took part in collection of NWFP [55], much also can be considered unrecorded informal collection. This diversity of goods provided freely from natural forests, woodlands and grasslands is rightly referred to as "the hidden harvest" due to the absence of official statistics [59], and is common in similar forest-based economies around the world.

The broad range of NWFP and services is essential for people's livelihoods [64] around the world. In SSA, they are particularly important to rural communities for nutritional, medicinal, material, cultural, spiritual, environmental and ecological benefits [16, 37, 65-67]. Food security and adequate nutrition contribute to human development, and for many people, forests and associated NWFP are closely linked to the four dimensions of food security (availability, access, use and stability), notably during particular seasons of the year [21], and increase dietary diversity [68]. As food shortages and poor nutrition remain major problems in SSA, the consumption of wild edibles is common providing much needed dietary diversity to address among the rural and peri-urban populations [66-70]. Hence, non-market values of NWFP in SSA, and in countries with similar situations, are crucial as they provide nutrients to support good health that is foundational for economic development [37].

\section{Managing the Resource}

Most cultures have customary forest laws, bylaws and regulations that were established due to a conscience need for resource conservation and protection of access and property rights (e.g. [71, 72]). Established property rights influence the collection and marketing of NWFP, as they govern access and 
harvest of forest resources [73, 74]. According to the 8th Chinese Forest Resources Inventory, traditional NWFP are planted mainly on collectively owned land and managed by individual workers [75]. In some parts of Europe (e.g. Croatia, Cyprus, France, Lithuania, Spain, Turkey and the UK), the produce of a specific land holding is the property of the landowner, and removal of products without permission may constitute common law theft $[71,72]$. In many other countries (e.g. Austria, Bulgaria, Czech Republic, Hungary, Nordic countries and Slovakia), NWFP collection is considered "everyman's rights" meaning that they are not private property and the right to collect them remains in the public domain [71, 72, 76, 77]; however, specific regulations, restrictions and prohibitions within such "everyman's right" are common [78]. Similarly, in the USA and in Russia, many NWFP are treated as open-access resources with little restriction on harvest and no management to encourage regrowth after harvesting $[79,80]$.

Sustainable management of the non-wood forest resources in India is the joint responsibilities of the national and provincial governments. In 1988, the National Forest Policy, of India, resulted in a revolutionary shift from regulatory to participatory approach to forest management [81]. Successive forest policy statements have directed attention to the production and trade in NWFP. National legislation (e.g. "Panchayats (Extension to Scheduled Areas) Act 1996" (a.k.a. PESA)) provides ownership of NWFP to Gram sabhas/panchayats (village assemblies). Following legislation entitled "Scheduled Tribes and Other Traditional Forest Dwellers Act 2006" (a.k.a. Recognition of Forest Rights/FRA) gave forest-dependent communities a primary role in forest management. This act directs that "ownership" includes revenue from sale of usufructuary rights that is the right to net revenue after retaining the administrative expenses of the department, additional to the right to regulate access and to control the resource or product [82]. These and other policies indicate a developing awareness of the need to regulate use and exploitation; stakeholder involvement in these is essential in the transitioning process.

\section{Status Quo Management of NWFP Resources}

Paradoxically, some tenure systems, especially common property regimes and short-term leases, create conditions under which NWFP can be over-exploited and degraded when regulations are lacking [83]. The conservation and sustainable use of commercially important NWFP resources is a challenging task. Increased commercial utilisation of these resources can entice local communities to over-exploit the products, while ignoring traditional harvesting practices that may be sustainable, which can have significant impacts on the resource base. For example, of the 8000 species of medicinal plants found in India, around 1000 are facing various degrees of threat across bio-geographic regions [84]. Many raw materials are unsustainably harvested, depriving socio-cultural and economic benefits to local communities [85, 86]. The implications of everyman's rights to NWFP as simply unregulated collection [87] where the number of harvesters, and the locations, timing and access of harvests are unrestricted, can put species populations at increased risk $[85,88]$. Bio-economic evidence of this has been observed in fisheries and forestry where there is no investment in management $[83,89,90]$ resulting in a backward bending long run supply curve. Frey et al. [91] provided empirical evidence of such a situation with American ginseng; long-term, the quantities supplied appear to be negatively related to price, the opposite of the law of supply. Without sustainable forest management and good practices, other NWFP could face a similar situation. A transitioning process will require determining ways to ensure that harvesting is in fact sustainable.

A common contention relative to developing regions is that people degrade their natural resources out of necessity to cope with food insecurity $[92,93]$. Land use and land use changes due to population growth and inappropriate environmental and agricultural management practices have led to rapid soil and land degradation [94], a direct threat to food security and subsistence and intrinsically linked to overexploitation of NWFP that are already under extreme pressures. In recent years, SSA farmers have realised that traditional management practices no longer address their needs due to land use pressures, changing climate and changes in the rules regarding land ownership and access to resources. In Ethiopia, studies indicate that frankincense (Boswellia papyrifera (Delile ex Caill) Hochst.) populations are declining at an alarming rate, aggravated mainly due to irrational and unsustainable natural resources management and overexploitation [95]. Production volume for frankincense is expected to decrease by $50 \%$ in the next 15-20 years, and the entire resource could disappear within 60 years if current lack of management continues [96]. This situation is reflected in many other developing tropical countries where commercialisation and increased demand leads to overharvesting [55]. In the north of Mali, rural populations have resorted to importing baobab (Adansonia digitata L.) leaves to complement their diet [97] because traditional management practices for the production or sustainable collection of this NWFP have not adapted to the current environment. However, the outlook may be optimistic in other areas, such as Niger, as local communities regard utilisation of NWFP resources as a priority for conservation [98].

The vulnerability of plant species to overharvesting, habitat losses and climate change is a crucial consideration in sustainable management $[10,85]$. The potential for sustainable harvest of a NWFP species is influenced by the desired plant part, habitat requirements, population size, species distribution, reproductive mechanisms and many other factors [86]. Common and widespread species that reproduce rapidly and asexually 
and valued for parts that have little impact on adult mortality or regeneration have higher potential for sustainable harvests [99]. Conversely, greater concern for unsustainable harvests should be directed to plants that are uncommon, with limited habitat or distribution, reproduce slowly or erratically, and are harvested for organs that increase mortality [86]. Understanding ecological dynamics associated with harvesting is critical in transitioning to sustainable co-production management.

\section{Discussion: Transitioning from the Status Quo}

In the eighteenth century, a growing European population and industrialisation had exacerbated a scarcity of timber and fuel that led to the development of a timber revenue-based utilisation of forests that integrated silviculture linking the concept of sustainable yield with effective management practices. Such a timber-oriented forest management approach has been associated with neglect of other forest functions, including production of NWFP. This narrow single-purpose, command-and-control approach strongly influenced forest management practices on a global scale [100]. Forest management exclusively for wood products, to the detriment of other forest ecosystem services, is unsuitable in coping with challenges that affect forests and the people who depend on them [11]. Timber-oriented forest management does not adequately capture the complexity and diversity of provisioning NWFP ecosystem services. Sustainable forest management (i.e. the application of the ecosystem management practices) [5] implies that production of NWFP is viable in perpetuity from a forest with no long-term impacts on the species or populations being harvested. Sustainable harvest of a resource ensures an undiminished flow of benefits from the resource to its users over time with no deleterious effect on regeneration of target population or any other associated species or on ecosystem structure and functioning.

Previous work on this subject addressed some issues relating to frameworks for sustainable forest management with the integration of NWFP commodities, e.g. [101-103]. We propose a conceptual framework for transitioning to sustainable co-production management for timber and NWFP (Fig. 1). The status quo represents a generalised current state of affairs where the single goal of wood production is paramount. Each node within the proposed framework describes a factor that is significant for transitioning towards sustainable co-production management. The main body of the framework is supported by the concept of complexity (forest ecosystems), regulation (governance) and by socio-economic demands (social system); these three primary nodes are supported by sub-nodes which describe the mechanisms that pressure the transition modifying the status quo. Finally, external influences are presented that signify stimuli which can motivate changes within the framework itself.
The three supporting pillars of the framework forest ecosystems, governance and social system are supported by subnodes that overlap and join thematic issues; their relevance to the framework is described below. Potential issues that might arise and possible solutions to these are outlined within Table 2. These sub-nodes include the following:

\section{Trade}

The economic value of NWFP commodities is a major driver for exploitation of available resources, demand drives production and leads to overexploitation, and regulation through policy and effective governance is required to ensure a sustainable supply. Global, national and local commerce provides the impetus for research as it provides an economic worth to the resource as well as cross-sectoral influence in social and political areas that can shape the future of available resources. A transitioning from the status quo requires a continued market demand balanced with supply. Imbalance within this equation can lead to a breakdown of the system and impede the transition process.

\section{Livelihoods}

NWFP production and trade generates food security and employment and contributes to household incomes, hence contributing to livelihoods, food security and development. Local sales of NWFP often supplement overall household income. Studies of micro-enterprises in SSA demonstrated that most people who sell NWFP do so as individuals or as small family operations [37], and the amounts traded are relatively small in quantity and value.

\section{Cooperation Networks and Empowerment}

Social cooperation, engagement and empowerment are essential to transition from the status quo to sustainable co-production management. Overlying potential compromise for coproduction is the simple issue that in many cases "those that invest, do not reap the benefits" [104, 105], i.e. innovations in silvicultural regime must be followed by clear benefits for those undertaking, and paying for, the forest management. An everyman's right to harvest applies to particular wild-collected resources for the benefit of the general population; however, forest management and silviculture are controlled by (private and state) forest managers and landowners targeting a timberoriented goal. A challenge is to establish integral forest ecosystem governance mechanisms that simultaneously satisfy multiple stakeholder interests [100]. NWFP is often seen in a positive sense as green, traditional and local [36]. An increasing number of stakeholders recognised in forest governance, significant global climate change uncertainties, greater impacts from pests and diseases, and ongoing land uses changes and degradation demand fores $t$ policies that support sustainable management 
Fig. 1 A conceptual framework for transitioning to sustainable coproduction management for timber and NWFP

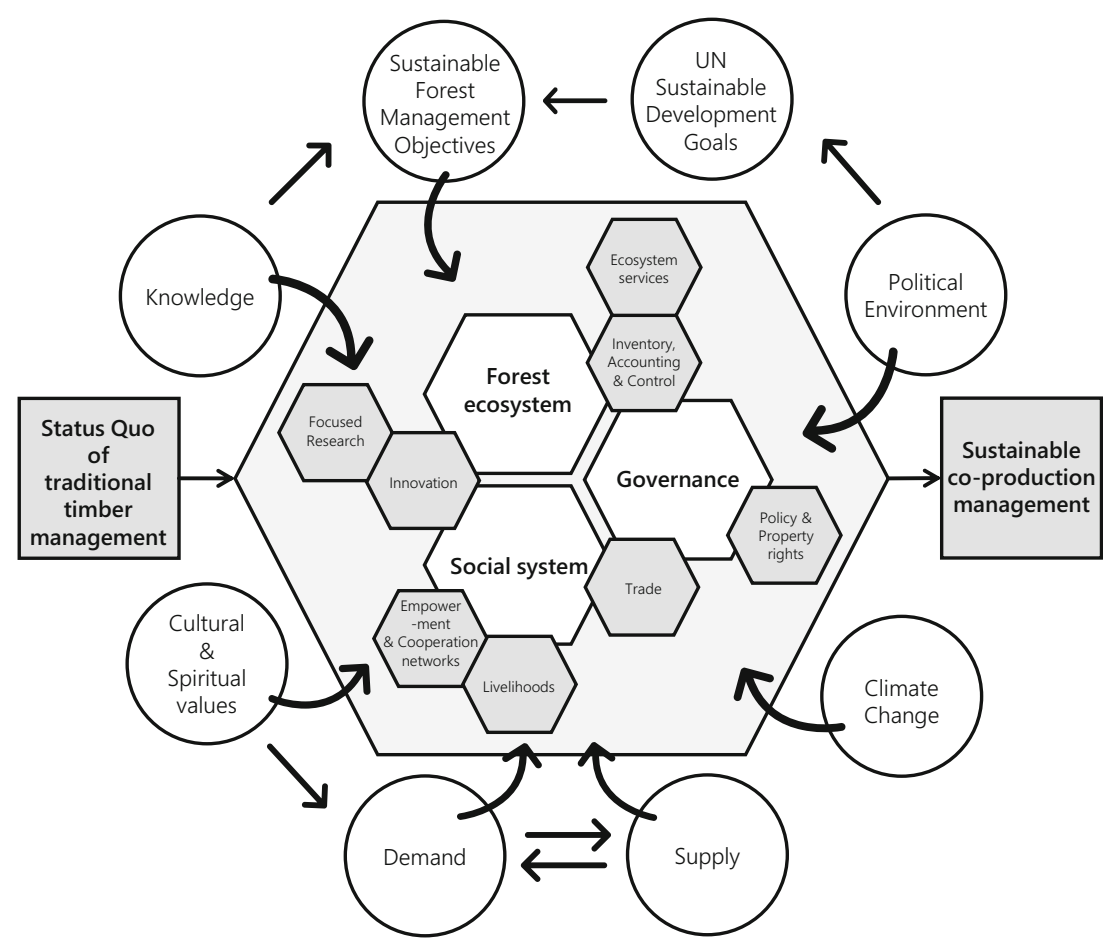

Innovation

approaches that are more flexible [100]. Such public interest in natural resources and associated ecosystem services are increasing as part of a new mindset aligned with the ideals of a biobased economy. Stakeholder participation within political, governance and research groups can provide social empowerment delivering the motivation for changes at a grassroots level and pressure for legislative bodies for a transition from the status quo.

\section{NWFP Inventory, Accounting and Control}

Modified trade classification systems for the efficient accounting of NWFP trade are needed to make this transition. Utilising multi-digit coding, the harmonised commodity description and coding system developed by the World Customs Organization can be used to describe NWFP commodity groups both as raw or end-use products. A standardised system provides distinct advantages that can separate wild from cultivated products and a degree of transparency in trade [36]. Certification for products that are sustainably managed is paramount for the transitioning process. Globally, forest certification was primarily developed for timber through certification organisations such as FSC (Forest Stewardship Council) and PEFC (Programme for the Endorsement of Forest Certification Schemes); however, adaptations for sustainable production of NWFP are now accepted. As example, NWFP certification standards as developed by the Rainforest Alliance's NTFP marketing and management project [106] have been adopted. Certification for NWFP also can extent to wild labelling and alliance with eco/organic/social-economic or even geographical branding [36].
The employment of innovative strategies is expected to play an important role within the transformation of the NWFP sector, leading to the introduction of new products and processes in production. Innovation also can take the form of organisational, marketing, policy, institutional, silvicultural technique or social innovations, thus rendering it a cross-sectoral and multidimensional theme within NWFP co-production management. Future innovation strategies may include the fostering of urbanrural interactions, the support for bottom-up innovations and the establishment of systemic NWFP development support through research and development, education and training [107].

\section{Ecosystem Services}

The trending focus on integration of forest ecosystem services beyond sourcing of raw materials is to embrace regulating, habitat and cultural services [6]. An integrated approach of sustainable co-production can be harmonised with wider sustainable forest management goals motivated by climate change and policy drivers that enhance or promote forest functions and associated ecosystem services.

Transitioning to sustainable co-production forest management requires the same type of species-specific knowledge needed to manage timber trees [85]. According to Chamberlain et al. [85, 86], a starting point for determining sustainable harvest levels is an inventory of harvestable stock, estimates of annual incremental growth, transparent and reliable reporting of amounts harvested each year, and estimates 
Table 2 Issues and possible solutions for sustainable co-production management

\begin{tabular}{|c|c|c|}
\hline Framework node & Issues & Possible solutions \\
\hline \multirow[t]{2}{*}{ Innovation } & $\begin{array}{l}\text { NWFP are rarely explicit objectives of forest } \\
\text { management, the focus remains on wood } \\
\text { production, management planning does not } \\
\text { reflect the diversity and complexity of NWFP } \\
\text { species }\end{array}$ & $\begin{array}{l}\text { - Management planning } \\
\text { - Integrated solutions: integration of sustainable } \\
\text { co-production systems } \\
\text { - Explicit objectives to manage for NWFP } \\
\text { - Establish policies that mandate and provide } \\
\text { support for management }\end{array}$ \\
\hline & $\begin{array}{l}\text { Land degradation and declining natural } \\
\text { populations, traditional land management no } \\
\text { longer addresses the needs }\end{array}$ & $\begin{array}{l}\text { - Effective strategic policy } \\
\text { - Innovative land management practices suited to } \\
\text { changing conditions and demands }\end{array}$ \\
\hline \multirow[t]{3}{*}{$\begin{array}{l}\text { Inventory, accounting } \\
\text { and control }\end{array}$} & $\begin{array}{l}\text { Production figures are inadequate and } \\
\text { incomplete, discrepancies in estimates of } \\
\text { global economic values }\end{array}$ & $\begin{array}{l}\text { - Need for a global standardised measurement } \\
\text { and method of accountancy } \\
\text { - Global cooperation and collaboration in } \\
\text { establishing standard measures }\end{array}$ \\
\hline & $\begin{array}{l}\text { Under regulation and overharvesting of the } \\
\text { resource }\end{array}$ & $\begin{array}{l}\text { - Need for NWFP accounting } \\
\text { - Target research on sustainable harvest levels } \\
\text { - Systems that encourage participation of } \\
\text { stakeholders }\end{array}$ \\
\hline & $\begin{array}{l}\text { NWFP rarely included in forest inventory and } \\
\text { analysis }\end{array}$ & $\begin{array}{l}\text { - Call for adoption of integrated approaches } \\
\text { - Requirement for increased awareness of } \\
\text { multi-functional/use forest management }\end{array}$ \\
\hline \multirow[t]{2}{*}{ Trade } & $\begin{array}{l}\text { International NWFP markets are complex and } \\
\text { risky, NWFP markets are not fully understood }\end{array}$ & $\begin{array}{l}\text { - Targeted research } \\
\text { - Explicitly define market structure }\end{array}$ \\
\hline & Much NWFP is traded informally & $\begin{array}{l}\text { - Better understanding of non-market values } \\
\text { - Targeted research to understand non-market } \\
\text { trading }\end{array}$ \\
\hline Policy & $\begin{array}{l}\text { Political and institutional frameworks are } \\
\text { underdeveloped }\end{array}$ & $\begin{array}{l}\text { - Targeted research } \\
\text { - Feedback mechanisms from stakeholders to } \\
\text { policymakers }\end{array}$ \\
\hline \multirow[t]{4}{*}{$\begin{array}{l}\text { Cooperation networks } \\
\text { and empowerment }\end{array}$} & Those that invest do not reap the benefits & $\begin{array}{l}\text { - Feedback mechanisms from stakeholders to } \\
\text { policymakers }\end{array}$ \\
\hline & $\begin{array}{l}\text { Forest managers lack skills and inventive to } \\
\text { manage effectively for NWFP }\end{array}$ & $\begin{array}{l}\text { - Innovation, NWFP development support } \\
\text { through research and development, education } \\
\text { and training }\end{array}$ \\
\hline & $\begin{array}{l}\text { NWFP are sensitive to consumer preference and } \\
\text { quality considerations }\end{array}$ & $\begin{array}{l}\text { - Targeted research } \\
\text { - Social marketing to advocate participation of } \\
\text { stakeholders }\end{array}$ \\
\hline & $\begin{array}{l}\text { Property rights affects the availability and } \\
\text { sustainability of the resource }\end{array}$ & $\begin{array}{l}\text { - Effective strategic policy } \\
\text { - Governance systems that encourage } \\
\text { participation at all levels }\end{array}$ \\
\hline External influences & $\begin{array}{l}\text { Climate change threats to NWFP species, their } \\
\text { production and natural environments }\end{array}$ & $\begin{array}{l}\text { - Social and political cooperation, } \\
\text { - Effective strategic policy } \\
\text { - Integrated solutions }\end{array}$ \\
\hline
\end{tabular}

of amounts lost through mortality. The ensuing equation for sustainable management for NWFP, albeit simple, is challenging, if not impossible to obtain without reliable estimates documented for all elements needed to make it accurate. In addition, to a lack of science-based knowledge, achieving sustainable co-production is challenged by the fact that forest foragers often prefer to remain unknown and are secretive about harvest locations and quantities extracted. Yet, local and traditional ecological knowledge may be crucial to sustainable management $[85,86]$. Even for those products that are in the formal economy, there has not been a concerted effort to track, monitor and harmonise production amounts [108]. These challenges are not overwhelming, but will require years of focused and integrative research to provide a foundation for sustainable co-production and management of forest ecosystems.

\section{Policy Driving Change}

Policy increasingly recognises NWFP as a significant component of multi-purpose functioning of forest management [109]. Policy and governance reflect a right of access where harvesters are subject to conditions, restrictions and prohibitions. Often strategic policy is absent; policies often are introduced in 
reaction to the perceived risk of overexploitation, resulting in harvest limits or restrictions on harvesting season [78]. Around the world, NWFP are increasingly recognised as natural resources of value to manage. In a review of US national forest management plans, Chamberlain [110] found that $23 \%$ of the federal national forests in eastern United States identified NWFP as management opportunities. Specific products were identified as important for management, and actions were chartered to ensure their production, and conservation. The situation in the western United States is different as NWFP are more widely distributed and a more prominent part of the economy. Meanwhile, in 2013, "A new EU Forest Strategy: for forests and the forest-based sector" [109] committed the European Union to using sustainable forest management methodologies to balance forest functions, while meeting demands and ecosystem services in supporting a forest-based value chain, recognised as a valuable contributor to a bio-based economy.

One example of transition can be seen in Russia. Historically, Russian forest management was an extensive model focused on continuous exploitation of the territories, which reached natural limits and led to decreased forest resources and ecological decline, due to an inherent lack of management. Such an overarching management model does not meet the goals for sustainable forest management, based on a balance of economical, ecological and social interests [111, 112]. A diversity of habitats, and complex species and age structures of Russian forests, implies a vast diversity of NWFP resources and this requires acknowledgement as a basis for sustainable forest management [49, 50]. Recognising the need for change in governance approach, the 2007 legalisation "The Forestry Code" stipulates and regulates community-forest relations in Russia [80]. The code changed distribution of power between federal and regional governments, economic entities, funding system, access rights and forest planning and inventory. Formal federal ownership of the forests is retained by the state and administered by the Federal Agency of Forestry, but forest management was transferred to the regional governance. Today, there is growing demand in Russian society for the effective stewardship of NWFP and other forest ecosystem services [50]. While in India, NWFP has been recognized at the forest division working plan level which places a mandatory requirement to practice sustainable management.

\section{Sustainable Co-production Management for Multiple Products}

Generally, NWFP stocks show declining trends when not actively managed or cultivated (e.g. forest farming, agroforestry), with significant economic ramifications that have yet to be accurately accounted for. Rapid population growth, urbanisation and demand for other forms of land use have put NWFP under great pressure. Realising sustainable forest management for these products is particularly challenging because wildcollected plants, animals and fungi are seldom considered in forest management plans, nor accounted. In general, forest management agencies perceive the products as insignificant sources of revenues, and their harvesting as having low impacts on forest health. But essentially, forest managers lack the necessary botanical and socio-economic information, and technical skills to innovate when contemplating sustainable management for NWFP (see Table 2). That said, awareness of their importance is increasing rapidly, and actions are being taken to advance sustainable forest management for NWFP through innovation, action research, training and stakeholder education.

The impacts of forest activities affect all associated flora and fauna, and isolating the impact of one is complicated by many interacting factors. The impacts of timber harvesting on NWFP species are not always well understood [113, 114] making coproduction management challenging. The effects of removing trees on associated plants can be difficult to determine because responses are based on severity of disturbance, site conditions, climate variability, among other factors [115]. Gaps created by changes in canopy affect soil moisture and temperature and increased light to the understory can positively and negatively affect growth, reproduction and yields of associated NWFP species [116-119]. Gaps can provide habitat for invasive and early successional species that may compete with preferred NWFP species. Innovating silvicultural treatments designed for timber-oriented forest management may encourage NWFP production $[120,121]$. These and many other considerations are necessary for transitioning to sustainable co-production management silvicultural practices and policies appropriate for NWFP.

There is some evidence from around the world that countries are starting to address this transition. In China, silvicultural practices have developed over centuries for co-production of traditional NWFP. Based much on traditional knowledge, NWFPoriented silvicultural practices are common in many regional cultures. Recently, the Chinese national government established policies and plans to promote development of NWFP production systems [122]. While in India, the integration of NWFP into sustainable forest management is reflected in the country's $12^{\text {th }}$ planning commission report. The direction espoused is a participatory approach involving local forest-dependent user communities as an essential tool for achieving sustainable forest management and in situ conservation of indigenous forest resources.

Integration of NWFP into sustainable co-production management for wood and non-wood requires several major considerations $[85,86,104,105,123]$ and may demand an element of silvicultural innovation [25, 117]. Compatible management, defined as the concurrent production of multiple products without significant decrease in other values (cf. [124]), presents a complex set of challenges relative to the diversity of species, products, markets, stakeholders and agencies. The sheer number of plants and fungi overwhelms many efforts to determine best management practices. For many species, little is known about individual and population biology and ecology, let alone sustainable management practices $[85,86]$. Slight ecological differences 
between species and habitats can make sustainable management challenging. For example, the timing of timber harvest may reduce stress on some understory species while impacting others disproportionately. In the long-run, stand rotation lengths for regeneration cutting may need to be increased to mitigate disturbances to NWFP. A forest managed for hardwood timber may require 80-120-year harvest rotations, but during that period, more than four harvests of medicinal forest products, and annual collection of others, may be possible. Another challenge in coproduction occurs when the species is desired for its wood and non-wood values; sugar maple (Acer saccharum Marshall) is valued and managed for its sap and wood. Managing for one value impacts production of the other, and consideration of both products is necessary for successful co-production [85]. Alternatively, instead of aiming to maximise NWFP yields in all stands, prioritisation of only the most suitable stands for coproduction management could be targeted [115].

\section{Conclusions}

Knowledge gaps persist about the contributions of NWFP to global, national, regional and local economies and human well-being. Harvest, revenue and trade figures are incomplete, given the prevalence of foraging for self-consumption, bartering or informal local markets, whose volume is only indirectly estimated from expert opinion [33] or by surveys $[59,62]$. The role of many NWFP in rural livelihoods has not been comprehensively examined through science, despite a growing understanding of the importance of NWFP and their innovation potential for a bio-based economy. They are increasingly recognised for their contributions to food security, poverty reduction and sustainable development $[1,33]$.

The integration of timber-oriented forest management and NWFP supply chains into a conceptual framework of sustainable co-production management for provisioning of multiple products requires knowledge from long-term research on the biology of relevant species, populations and ecosystems. It requires estimates of actual annual harvest yields, the impacts of pest and diseases, and of climate and land use changes on them. Furthermore, it requires information regarding the supply and value chains and trade flows of these natural resources [108].

Political willingness, administrative capabilities and social cooperation are keys to implement operative NWFP sustainable harvesting and management that requires sound governance principles. Robust reporting systems for NWFP sourcing at national and international scales imply transparency, and due diligence in traceability and accountability. Improved forms of forest governance that involve NWFP stakeholders at different levels in decision-making will take advantage of the cultural and traditional interest of wildcollected products for the sake of rural community development and conservation of important NWFP resources [125].
Sustainable co-production management of wood and NWFP must be placed within a conceptual framework that embraces social-economic issues, governance and natural resource focal points. Whereas timber-oriented forest management has evolved in the last three centuries as a science-based discipline, the conceptual integration of NWFP goods and services in forest management and planning has remained limited. Such products have been neglected or considered restrictive to timber optimisation; timber-oriented management dominates in many temperate European countries with high growth rates that favour plantation forestry with spruce or pines. On the contrary, the economic relevance of NWFP for local livelihood and income is recognised increasingly in many countries. With all elements considered, fulfilling the individual requirements of social cooperation, NWFP accounting, management innovation and forest governance, transitioning to sustainable coproduction management for NWFP is possible for integration into a fully functioning bio-based economy.

Acknowledgements This review was coordinated under the framework of the IUFRO Research Groups 1.08 "Silviculture for Production of Edible Fruits" and 5.11 "Non-Wood Forest Products". We recognise and appreciate the fruitful discussions and mutual learning with colleagues of the project consortia reflected in this piece. We thank two anonymous reviewers whose comments helped improve and clarify this manuscript.

Funding Information Open Access funding provided by Projekt DEAL. The authors thank the European Commission for support of their research by the past European FP7 project StarTree, grant agreement 311919, the COST Action FP1203 on NWFPs, as well as the ongoing H2020 Thematic network INCREDIBLE, grant agreement 774632. The BMBF funded SPACES2 project ASAP, grant agreement 01LL1803A, and National Key R\&D Program of China grant agreement 2017YFD0600600.

\section{Compliance with Ethical Standards}

Conflict of Interest Jonathan Sheppard reports grants from the German Federal Ministry of Education and Research, during manuscript preparation. Sven Mutke reports grants from European Union's Horizon 2020 research \& innovation programme, during manuscript preparation; James Chamberlain, Dolores Agúndez, Prodyut Bhattacharya, Paxie Wanangwa Chirwa, Andrey Gontcharov, Willie Cliffie John Sagona, Hai-long Shen, and Wubalem Tadesse declare that they have no conflict of interest.

Human and Animal Rights and Informed Consent This article does not contain any studies with human or animal subjects performed by any of the authors.

Open Access This article is licensed under a Creative Commons Attribution 4.0 International License, which permits use, sharing, adaptation, distribution and reproduction in any medium or format, as long as you give appropriate credit to the original author(s) and the source, provide a link to the Creative Commons licence, and indicate if changes were made. The images or other third party material in this article are included in the article's Creative Commons licence, unless indicated otherwise in a credit line to the material. If material is not included in the article's Creative Commons licence and your intended use is not permitted by statutory regulation or exceeds the permitted use, you will need to obtain permission directly from the copyright holder. To view a copy of this licence, visit http://creativecommons.org/licenses/by/4.0/. 


\section{References}

Papers of particular interest, published recently, have been highlighted as:

- Of importance

•- Of major importance

1• FAO (Food and Agriculture Organization of the United Nations). The state of the world's forests, 2018: forest pathways to sustainable development. Rome: Food and Agriculture Organization of the United Nations; 2018. The State of the World's Forests 2018 provides detailed analysis aimed at capturing the contribution of forests and trees to 28 targets relating to ten sustainable development goals.

2 Chao S. Forest peoples: numbers across the world. UK: Moretonin-Marsh; 2012.

3 FAO (Food and Agriculture Organization of the United Nations). Forests and the forestry sector. 2016. http://www.fao.org/forestry/ country/57478/en/ind/. Accessed 6 Mar 2019.

4 UNCED. Report of the United Nations Conference on Environment and Development. Annex III. Non-legally binding authoritative statement of Principles for a global consensus on the management, conservation and sustainable development of all types of forests: A/CONF.151/26 (Vol. III); 1992.

5 Secretariat of the Convention on Biological Diversity. The ecosystem approach: CBD Guidelines 2004. Montreal.

6 Maes J, Paracchini ML, Zulian G. A European assessment of the provision of ecosystem services: towards an atlas of ecosystem services. Luxembourg: Publications Office; 2011.

7 Berrahmouni N, Regato P, Parfondry M. Global guidelines for the restoration of degraded forests and landscapes in drylands: building resilience and benefiting livelihoods. Food and Agriculture Organization of the United Nations: Rome; 2015.

8 Belcher BM. What isn't an NTFP? Int For Rev. 2003;5:161-8. https://doi.org/10.1505/IFOR.5.2.161.17408.

9 Chamberlain JL, Mitchell D, Brigham T, Hobby T, Zabek L, Davis J. Forest farming practices. In: Garrett HE, editor. North American agroforestry: an integrated science and practice. 2nd ed. Madison WI: American Society of Agronomy; 2009. p. 219-55.

10 Sheppard JP, Santos e Silva C, Louro R, Stara K, Belova O, Spiecker H. Identification and ecology of NWFP species. In: Vacik H, Hale M, Spiecker H, Pettenella D, Tomé M, editors. Production and Outcomes of the COST Action FP1203: European non-wood forest products (NWFPs) network.; Forthcoming.

11 FAO (Food and Agriculture Organization of the United Nations). Towards a harmonized definition of non-wood forest products. 1999. http://www.fao.org/3/x2450e/x2450e0d.htm\#fao\% 20forestry. Accessed 25 Apr 2019.

12 Chamberlain J, Bush R, Hammett AL. Non-timber forest products: the other forest products. For Prod J. 1998;48:10-20.

13 Secretariat of the Convention on Biological Diversity. Sustainable management of non-timber forest resources. Montreal; 2001.

14•• Chamberlain JL, Emery MR, Patel-Weynand T. Assessment of nontimber forest products in the United States under changing conditions. Asheville, NC: Forest Service; 2018. This report is a forest-sector-wide assessment of the state of the knowledge regarding NTFP science and management information for US forests and rangelands.

15 FAO (Food and Agriculture Organization of the United Nations). Forests, trees and food. 1992. http://www.fao.org/3/u5620e/ U5620E00.HTM.
16 Deafalla THH, Dafa-Alle DM, El Abbas MM. The importance of non wood forest products for rural livelihoods: the case of South Kordofan state, Sudan. In: Behnassi M, Shahid SA, Mintz-Habib $\mathrm{N}$, editors. Science, policy and politics of modern agricultural system: global context to local dynamics of sustainable agriculture. / Mohamed Behnassi, Shabbir A. Shahid, Nazia Mintz-Habib, editors. Dordrecht: Springer; 2014. p. 323-332.

17 Maghembe JA. Achievements in the establishment of indigenous fruit trees of miombo woodland of southern Africa. In: Maghembe JA, Ntupanyama Y, Chirwa PW, editors; 23-27 January 1994; Mangochi, Malawi. Nairobi: International Centre for Research in Agroforestry; 1995.

18 Saka DJ. The nutritional value of edible fruits. In: Maghembe JA, Ntupanyama Y, Chirwa PW, editors; 23-27 January 1994; Mangochi, Malawi. Nairobi: International Centre for Research in Agroforestry; 1995.

19 Muok BO, Owuor B, Dawson I, Were J. The potential of indigenous fruit trees: results of a survey in Kitui District, Kenya. Agroforestry today. 2001;12:13-5.

20 Egea I, Sánchez-Bel P, Romojaro F, Pretel MT. Six edible wild fruits as potential antioxidant additives or nutritional supplements. Plant Foods Hum Nutr. 2010;65:121-9. https://doi.org/10.1007/ s11130-010-0159-3.

21 Arnold JEM, Ruiz PM. Can non-timber forest products match tropical forest conservation and development objectives? Ecol Econ. 2001;39:437-47. https://doi.org/10.1016/S0921-8009(01) 00236-1.

22 Guariguata MR, García-Fernández C, Sheil D, Nasi R, HerreroJáuregui C, Cronkleton $\mathrm{P}$, et al. Compatibility of timber and nontimber forest product management in natural tropical forests: perspectives, challenges, and opportunities. For Ecol Manag. 2010;259:237-45. https://doi.org/10.1016/j.foreco.2009.11.013.

23 Morhart CD, Douglas GC, Dupraz C, Graves AR, Nahm M, Paris P, et al. Alley coppice - a new system with ancient roots. Ann For Sci. 2014;71:527-42. https://doi.org/10.1007/s13595-014-0373-5.

24 Sheppard JP. Options for management of high value timber within temperate agroforestry systems [doctoral thesis]. Freiburg im Breisgau: Albert-Ludwigs-Universität Freiburg i. Br.; 2016.

25 Tomé M, Cañellas I, Bonet JA, Paulo JA, Palma JHN, Martínez de Aragón J, et al. Resource and management: novel management concepts to boost product diversity and higher product flows. In: Wolfslehner B, Prokofieva I, Mavsar R, editors. Non-wood forest products in Europe: seeing the forest around the trees. Joensuu: European Forest Institute; 2019. p. 104-110.

26 Taylor DA. Ginseng, the divine root: the curious history of the plant that captivated the world. 1st ed. Chapel Hill, NC: Algonquin Books of Chapel Hill; 2006.

27 Bugge M, Hansen T, Klitkou A. What is the bioeconomy? A review of the literature. Sustainability. 2016;8:691. https://doi.org/ 10.3390/su8070691.

28・ Wolfslehner B. Non-wood forest products - an introduction. In: Wolfslehner B, Prokofieva I, Mavsar R, editors. Non-wood forest products in Europe: seeing the forest around the trees. Joensuu: European Forest Institute; 2019. p. 9-10. A comprehensive description of the current state of the art of the NWFP sector in Europe, providing analysis of the present situation with suggestions for future innovation.

29 Forest Europe. State of Europe's forests 2015; 2015.

30 Yin D, Li S, Wu, Quien, Feng, Chengyong, Li, Bing, Wang Q, Wang L, Xu W. Advances in research of six woody oil crops in China. Chinese Bulletin of Botany 2018;53:110-125.

31 Iqbal $M$. Trade restrictions affecting international trade in nonwood forest products. Food and Agriculture Organization of the United Nations: Rome; 1995.

32 Shanley P, Pierce AR, Laird SA, Binnqüist CL, Guariguata MR. From lifelines to livelihoods: non-timber forest products into the 
21st century. In: Pancel L, Köhl M, editors. Tropical Forestry Handbook. Berlin, Heidelberg: Springer Berlin Heidelberg; 2016. p. 2713-2760. doi:https://doi.org/10.1007/978-3-642-54601-3 209.

33 FAO (Food and Agriculture Organization of the United Nations). State of the world's forests. Enhancing the socioeconomic benefits from forests. Rome: Food and Agriculture Organization of the United Nations; 2014. p. 2014.

34 Vantomme P. FAO. Personal Communication.

35 EUROSTAT. Agriculture, forestry and fishery statistics: 2018 edition. Luxembourg; 2018.

36 Pettenella D, Corradini G, Da Re R, Lovric M, Vidale E. NWFPs in Europe - consumption, markets and marketing tools. In: Wolfslehner B, Prokofieva I, Mavsar R, editors. Non-wood forest products in Europe: seeing the forest around the trees. Joensuu: European Forest Institute; 2019. p. 31-53.

37 Agustino S, Mataya B, Senelwa K, Achigan-Dako GE, editors. Non-wood forest products and services for socio-economic development: a compendium for technical and professional forestry education. Nairobi, Kenya: The African Forestry Forum; 2011.

38 Chamberlain J, Teets A, Kruger S. Nontimber forest products in the United States: an analysis for the 2015 National Sustainable Forest Report. NC: Asheville; 2018.

39 Chamberlain JL, Prisley S, McGuffin M. Understanding the relationships between American ginseng harvest and hardwood forests inventory and timber harvest to improve co-management of the forests of Eastern United States. J Sustain For. 2013;32:605-24. https://doi.org/10.1080/10549811.2013.798828.

40 Farrell M, Chabot B. Assessing the growth potential and economic impact of the U.S. maple syrup industry. Journal of Agriculture, Food Systems, and Community Development. 2012;2:11-27. doi: https://doi.org/10.5304/jafscd.2012.022.009.

41 Handler SD, Swanston CW, Butler PR, La Brandt, Janowiak MK, Powers MD, Shannon PD. Climate change vulnerabilities within the forestry sector for the Midwestern United States. In: Winkler JA, Andresen JA, Hatfield JL, Bidwell D, Brown D, editors. U.S. National Climate Assessment Midwest Technical Input Report. Washington D.C.; 2012.

42 Stryamets N, Elkbakidze M, Chamberlain JL, Angelstam P. Governance of non-wood forest products in Russia and Ukraine: institutional rules, stakeholder arrangements, and decision-making processes. Land Use Policy. accepted October 2019:15pp.

43 Krasova EV, Sun Y. Features of development of food products and agricultural raw materials' export in Russian regions on example of the Far Eastern Federal District. RJOAS. 2017;64:203-12. doi: https://doi.org/10.18551/rjoas.2017-04.26.

44 Koraykin VN. Cedar-broadleaved forests in the Russian Far East (dynamics, condition, use of forest resources, rehabilitation). Khabarovsk; 2007.

45 Vivodtcev NV, Vivodtceva AN, Kobayashi R. Korean pine in the Khabarovsk Territory and outlook for its recovery. Khabarovsk; 2016.

46 Krechetova NV, Shteinikova VI. Korean pine fruiting. Khabarovsk; 1963.

47 Izmodenov AG. Overall evaluation of edible, medicinal, forage plant resources of the forest in the Far East. Lesnoe khoziaistvo. 1984;9.

48 Sukhomirov GI. Taiga wildlife management in the Russian Far East. Khabarovsk; 2007.

49 EIA. Liquidating the forests: hardwood flooring, organized crime and the world's last Siberian tigers. Washington, DC; 2013.

50 Lepeshkin E. Законодательные основы использования недревесных ресурсов леса: барьеры на пути развития сельских территорий и их преодоление [Legal framework for the use of NTFP: barriers to rural development and overcoming them]. In: WWF Russia, editor; 16.11.2018; Vladivostok; 16.11.2018.

51 Zhou L. The development situation of non-wood product forests in China and the supporting policy of national government - I. National Land Greening. 2018;1:39-41.

52 Kumar A, Kumar R, Lakhchaura PC. Global forest resources assessment 2015: country report India. Rome; 2015.

53 Joshi S. Super market, secretive. Exploitative, is the market in the minor forest produce unmanageable? Down to Earth. 2003;28.

54 Mitchell CP, Corrbridge SE, Jewitt SL, Mahapatra AK, Kumar S. Non timber forest products: availability, production, consumption, management and marketing in eastern India: final technical report; 2003

55 Wong JLG, Wiersum KF. A spotlight on NWFP in Europe. In: Wolfslehner B, Prokofieva I, Mavsar R, editors. Non-wood forest products in Europe: seeing the forest around the trees. Joensuu: European Forest Institute; 2019. p. 11-30.

56 Leakey RRB, Temu AB, Melnyk M, Vantomme P, editors. Domestication and commercialization of non-timber forest products; 1996.

57 Lowore J. Miombo woodlands and rural livelihoods in Malawi: an in-depth analysis and critical review based on literature research. Bogor, Indonesia: CIFOR; 2006.

58 Corona P, Cutini A, Chiavetta U, Paoletti E. Forest-food nexus: a topical opportunity for human well-being and silviculture. Annals of Silvicultural Research. 2016;40:1-10.

59 Angelsen A, Jagger P, Babigumira R, Belcher B, Hogarth NJ, Bauch S, et al. Environmental income and rural livelihoods: a global-comparative analysis. World Dev. 2014;64:12-28. https:// doi.org/10.1016/j.worlddev.2014.03.006.

60• Wiersum KF, Wong JLG, Vacik H. Perspectives on non-wood forest product development in Europe. International Forestry Review. 2018;20:250-62. doi:https://doi.org/10.1505/ 146554818823767546. This article analyses emerging perspectives on NWFP development in Europe and relates these to four main issues affecting NWFP developments in tropical countries.

61 Wong JLG, Prokofieva I, editors. Report presenting synthesis of regional sectoral reviews to describe the "State of the European NWFP": StarTree deliverable D1.3: European Commision; 2014.

62 Lovric M, Da Re R, Vidale E, Prokofieva I, Wong JLG, Pettenella D, Mavsar R. Collection and consumption of wild forest products in Europe . In: Startree, editor. Wild forest products in Europe; 1314 October 2016; Barcelona; 13-14 October 2016. p. 45.

63 Vacik H, Hale M, Spiecker H, Pettenella D, Tomé M, editors. Production and outcomes of the COST Action FP1203: European non-wood forest products (NWFPs) network.; Forthcoming.

64 Tieguhong JC, Ndoye O, Tchatat M, Chikamai B. Processing and marketing of non-wood forest products for poverty alleviation in Africa. Discov Innov. 2009;21:60-5.

65 Desalegn G, Tadesse W. Socio-economic importance and resource potential of non-timber forest products of Ethiopia. In: Tadesse W, Mbogga M, editors. First national workshop on non-timber forest products in Ethiopia; 5-6 April 2004; Addis Ababa, Ethiopia; 5-6 April 2004. p. 18.

66 Teketay D, Eshete A. Status of indigenous fruit in Ethiopia. In: Chikamai B, Eyog-Matig O, Mbogga M, editors. Review and appraisal on the status of indigenous fruits in eastern Africa: a report prepared for IPGRI-SAFORGEN in the framework of AFREA/ FORNESSA. Nairobi: Kenya; 2004. p. 3-35.

67 Balemie K, Kebebew F. Ethnobotanical study of wild edible plants in Derashe and Kucha districts, South Ethiopia. Journal of Ethnobiology and Ethnomedicine. 2006;2:53. https://doi.org/10. 1186/1746-4269-2-53

68- Rasolofoson RA, Hanauer MM, Pappinen A, Fisher B, Ricketts TH. Impacts of forests on children's diet in rural areas across 27 
developing countries. Sci Adv. 2018;4:eaat2853. doi:https://doi. org/10.1126/sciadv.aat2853. Innovative study linking forests to children's diet in developing countries; the study indicates that forest can attribute a greater dietary diversity to children who are exposed to forest ecosystems.

69. Akinnifesi FK, Kwesiga FR, Mhango J, Mkonda A, Chilanga T, Swai R. Domesticating priority miombo indigenous fruit trees as a promising livelihood option for small-holder farmers in Southern Africa. Acta Hortic. 2002;632:15-30.

70. Teklehaymanot T, Giday M. Ethnobotanical study of wild edible plants of Kara and Kwego semi-pastoralist people in Lower Omo River Valley, Debub Omo Zone, SNNPR, Ethiopia. Journal of Ethnobiology and Ethnomedicine 2010;6:23. doi:https://doi.org/ 10.1186/1746-4269-6-23.

71. Bauer J, Kniivilä M, Schmithüsen F. Forest legislation in Europe: how 23 countries approach the obligation to reforest public access and use of non-wood forest products. Geneva: United Nations; 2004.

72.• Nichiforel L, Keary K, Deuffic P, Weiss G, Thorsen BJ, Winkel G, et al. How private are Europe's private forests? A comparative property rights analysis. Land Use Policy. 2018;76:535-52. doi: https://doi.org/10.1016/j.landusepol.2018.02.034. A comprehensive European scale comparison of property rights relating to forests.

73. Bouriaud L. Property rights characteristics relevant for innovation and enterprise development in small-scale forestry. Small-scale Forestry. 2007;6:359-72. https://doi.org/10.1007/s11842-0079027-x.

74. Ostrom E, Schlager E. The formation of property rights. In: Hanna S, Folke C, Mäler K-G, editors. Rights to nature: ecological, economic, cultural, and political principles of institutions for the environment: Island Press; 1996. p. 127-156.

75. Yan R, Liang W. The theoretical analysis of non-wood product forest intensity lag and its revelation. China Price (Zhongguo Wujia). 2019;3:64-6.

76. Boa ER. Wild edible fungi: a global overview of their use and importance to people. Food and Agricultural Organization of the United Nations: Rome; 2004.

77. Ticktin T, Shackleton CM. Harvesting non-timber forest products sustainably: opportunities and challenges. In: Shackleton S, Shackleton CM, Shanley P, editors. Non-timber forest products in the global context. Heidelberg, London: Springer; 2011. p. 254-9.

78. Prokofieva I, Bouriaud L, Corradini G, Górriz E, KouplevatskayaButtoud I, Nichiforel L. Policy framework for -NWFPs - demands and barriers. In: Wolfslehner B, Prokofieva I, Mavsar R, editors. Non-wood forest products in Europe: seeing the forest around the trees. Joensuu: European Forest Institute; 2019. p. 55-74.

79. Frey GE, Blatner KA, Jacobson MG, Starbuck Downes CM, Sills EO, Mercer DE, et al. Economics of non-timber forest products. In: Chamberlain JL, Emery MR, Patel-Weynand T, editors. Assessment of nontimber forest products in the United States under changing conditions. Asheville, NC: Forest Service; 2018. p. 120-49.

80. Russian Federation. Forest code of the Russian Federation; 2006.

81. Bhattacharya P. Non-timber forest products (NTFPs) related policy and legal issues in India: promoting NTFP-based livelihoods for forest dwellers: results of a practitioner workshop. Hyderabad, Telangana; 2015.

82. Bhullar L. The Indian forest rights act 2006: a critical appraisal. Law, Environment and Development Journal. 2008;4/1:22-34.

83. Hardin G. The tragedy of the commons. Science. 1968;162:12438. https://doi.org/10.1126/science.162.3859.1243.

84. Ved DK, Goraya GS. Demand and supply of medicinal plants in India. NMPB, New Delhi \& FRLHT: Bangalore, India; 2007.
85. Chamberlain JL, Small CJ, Baumflek M. Sustainable production of temperate and boreal nontimber forest products: examples from North America. In: Stanturf J, editor. Achieving sustainable forestry: Vol. 1 Boreal and temperate forests. Cambridge: Burleigh Dodds Science Publishing; 2019.

86•• Chamberlain JL, Small CJ, Baumflek M. Sustainable forest management for nontimber products. Sustainability. 2019;11:2670. doi:https://doi.org/10.3390/su11092670. This article examines three elements of sustainable forest management for nontimber products (sociocultural, economic and ecological) and elaborates with detailed examples of edible and medicinal species from forests in the USA.

87. FAO. Report of the International Expert Consultation on NonWood Forest Products: Yogyakarta, Indonesia, 17-27 January 1995. Rome: Food and Agriculture Organization of the United Nations.

88. Schmidt JP, Cruse-Sanders J, Chamberlain JL, Ferreira S, Young JA. Explaining harvests of wild-harvested herbaceous plants: American ginseng as a case study. Biol Conserv. 2019;231:139 49. https://doi.org/10.1016/j.biocon.2019.01.006.

89. Gordon HS. The economic theory of a common-property resource: the fishery. J Polit Econ. 1954;62:124-42.

90. Binkley CS. Long-run timber supply: price elasticity, inventory elasticity, and the use of capital in timber production. Nat Resour Model. 1993;7:163-81. https://doi.org/10.1111/j.1939-7445. 1993.tb00145.x.

91. Frey GE, Chamberlain JL, Prestemon JP. The potential for a backward-bending supply curve of non-timber forest products: an empirical case study of wild American ginseng production. Forest Policy Econ. 2018;97:97-109. https://doi.org/10.1016/j. forpol.2018.09.011.

92. Richardson RB. Ecosystem services and food security: economic perspectives on environmental sustainability. Sustainability. 2010;2:3520-48. https://doi.org/10.3390/su2113520.

93. Torres-Vitolas CA, Harvey CA, Cruz-Garcia GS, VanegasCubillos M, Schreckenberg K. The socio-ecological dynamics of food insecurity among subsistence-oriented indigenous communities in Amazonia: a qualitative examination of coping strategies among riverine communities along the Caquetá River, Colombia. Hum Ecol 2019;47:355-368. doi:https://doi.org/10.1007/s10745019-0074-7.

94. UNEP. Sahel atlas of changing landscapes: tracing trends and variations in vegetation cover and soil condition. Nairobi: Kenya; 2012.

95. Tadesse W, Desalegn G, Alia R. Natural gum and resin bearing species of Ethiopia and their potential applications. Invest. Agrar: Sist. Recur. For. 2007;16:211. doi:https://doi.org/10.5424/srf/ 2007163-01010.

96. Eshete A. The frankincense tree of Ethiopia: ecology, productivity and population dynamics [doctoral dissertation]. Wageningen: Wageningen Universiteit; 2011.

97. Leach HB, van der Stege C, Vogl CR. Baobab (Adansonia digitata L.) and tamarind (Tamarindus indica L.) management strategies in the midst of conflict and change: a Dogon case study from Mali. Hum Ecol. 2011;39:597-612. https://doi.org/10.1007/s10745011-9415-x.

98. Moussa B, Nkonya E, Meyer S, Kato E, Johnson T, Hawkins J. Economics of land degradation and improvement in Niger. In: Nkonya E, Mirzabaev A, von Braun J, editors. Economics of land degradation and improvement - a global assessment for sustainable development. New York: Springer International Publishing; 2016. p. 499-539.

99. Ticktin T. The ecological sustainability of harvesting non-timber forest products: principles and methods. In: Shackleton CM, Pandey A, Ticktin T, editors. Ecological sustainability for non- 
timber forest products: dynamics and case studies of harvesting: Earthscan Routledge; 2015. p. 31-52.

100. Messier C, Puettmann K, Chazdon R, Andersson KP, Angers VA, Brotons L, et al. From management to stewardship: viewing forests as complex adaptive systems in an uncertain world. Conserv Lett. 2015;8:368-77. https://doi.org/10.1111/conl.12156.

101. Ruiz Pérez M. A conceptual framework for CIFOR's research on non-wood forest products: working paper 6. Jakarta, Indonesia: Center for International Forestry Research (CIFOR); 1995.

102. Dlamini CS, Geldenhuys CJ. Towards a theoretical framework for the management of non-timber forest products (NTFPs) in Swaziland: a review. Journal of Geography and Regional Planning. 2011;4:715-30.

103. Schunko C, Lechthaler S, Vogl C. Conceptualising the factors that influence the commercialisation of non-timber forest products: the case of wild plant gathering by organic herb farmers in South Tyrol (Italy). Sustainability. 2019;11:2028. https://doi.org/10. 3390/su11072028.

104. Sheppard JP, Mangold L, Spiecker H. Revised silvicultural guidelines for selected MPT and NWFPs: StarTree Deliverable 2.3. FP7 Project no 311919 KBBE.2012.1.2-06; 2016.

105. Sheppard JP. Multipurpose trees \& non-wood forest products: a challenge and opportunity for European silviculture. In: FVA Baden- Württemberg, editor; 18-22 September 2017; Freiburg, Germany. Freiburg: Forstliche Versuchs- und Forschungsanstalt (FVA) Baden-Württemberg; 2017. p. 616.

106. Yadav M, Dugaya D. Non-timber forest products certification in India: opportunities and challenges. Environ Dev Sustain. 2013;15:567-86. https://doi.org/10.1007/s10668-012-9393-1.

107. Weiss G, Ludvig A, Asamer-Handler M, Fischer CR, Vacik H, Zivojinovic I. Rendering NWFPs innovative. In: Wolfslehner B, Prokofieva I, Mavsar R, editors. Non-wood forest products in Europe: seeing the forest around the trees. Joensuu: European Forest Institute; 2019. p. 77-97.

108. Mutke S, Bonet JA, Calado N, Calvo J, Taghouti I, Redondo C, et al. Innovation networks on Mediterranean non-wood forest products. Journal of Innovative Science and Engineering. 2019;3:1-10.

109. European Commission. Communication from the commission to the European Parliament, the Council, the European Economic and Social Committee of the regions: a new EU Forest strategy: for forests and the forest-based sector. Brussels, Belgium; 2013.

110. Chamberlain JL. The management of national forests of Eastern United States for non-timber forest products [PhD dissertation]. Blacksburg, VA: Virginia Polytechnic Institute and State University; 2000.

111. Teplyakov VK. Current trends in the Russian Far East forest sector. For Sci Technol. 2011;7:103-9. https://doi.org/10.1080/ 21580103.2011.594603.

112. Kovalev AP, Matveev AG, Kovalev CA. Trends and state of the forest resources of the Far East. TOGU Vestnik. 2012;27:161-8.
113. Small CJ, McCarthy BC. Relationship of understory diversity to soil nitrogen, topographic variation, and stand age in an eastern oak forest, USA. Forest Ecology and Management 2005;217:229 243. doi:https://doi.org/10.1016/j.foreco.2005.06.004.

114. Elliott KJ, Vose JM, Rankin D. Herbaceous species composition and richness of mesophytic cove forests in the southern Appalachians: synthesis and knowledge gaps. The Journal of the Torrey Botanical Society. 2014;141:39-71. https://doi.org/10. 3159/TORREY-D-13-00054.1.

115. Kurttila M, Pukkala T, Miina J. Synergies and trade-offs in the production of NWFPs predicted in boreal forests. Forests. 2018;9:417. https://doi.org/10.3390/f9070417.

116. Whigham DF. Ecology of woodland herbs in temperate deciduous forests. Annu Rev Ecol Evol Syst. 2004;35:583-621. https://doi. org/10.1146/annurev.ecolsys.35.021103.105708.

117. Ellum DS. Demographic patterns and disturbance responses of understory vegetation in a managed forest of southern New England: implications for sustainable forestry and biodiversity maintenance $[\mathrm{PhD}$ dissertation]. New Haven, CT: Yale University; 2007.

118. Meier AJ, Bratton SP, Duffy DC. Possible ecological mechanisms for loss of vernal-herb diversity in logged eastern deciduous forests. Ecol Appl. 1995;5:935-46. https://doi.org/10.2307/2269344.

119. Duguid MC, Frey BR, Ellum DS, Kelty M, Ashton MS. The influence of ground disturbance and gap position on understory plant diversity in upland forests of southern New England. For Ecol Manag. 2013;303:148-59. https://doi.org/10.1016/j.foreco. 2013.04.018.

120. Pilz D, Molina R, Mayo J. Effects of thinning young forests on chanterelle mushroom production. Journal of Forestry. 104(1): 914. 2006;104:9-14.

121. Hummel S. Managing structural and compositional diversity with silviculture. In: Monserud RA, Haynes RW, Johnson AC, editors. Compatible forest management. Dordrecht: Kluwer Academic Publ; 2003. p. 85-119.

122. Zhou L. The development situation of non-wood product forests in China and the supporting policy of national government - II. National Land Greening. 2018;2:22-4.

123. Sheppard JP. Embracing compromise: forest management for wild forest products. Reforesting Scotland. 2017;55:14-5.

124. Monserud RA, Haynes RW, Johnson AC. Compatible forest management: background and context. In: Monserud RA, Haynes RW, Johnson AC, editors. Compatible forest management. Dordrecht: Kluwer Academic Publ; 2003. p. 3-32.

125. Agúndez D, Lawali S, Mahamane A, Alía R, Soliño M. Consumer preferences for baobab products and implication for conservation and improvement policies of forest food resources in Niger (West Africa). Econ Bot. 2018:1-15.

Publisher's Note Springer Nature remains neutral with regard to jurisdictional claims in published maps and institutional affiliations. 


\section{Affiliations}

Jonathan P. Sheppard ${ }^{1}$ (D) James Chamberlain ${ }^{2}$ (D) Dolores Agúndez $^{3,4}{ }^{(D)} \cdot$ Prodyut Bhattacharya $^{5}$ (D) Paxie Wanangwa Chirwa ${ }^{6}$ (I) $\cdot$ Andrey Gontcharov $^{7}$ (I) - Willie Cliffie John Sagona ${ }^{8} \cdot$ Hai-long Shen $^{9}$ (D) Wubalem Tadesse ${ }^{10} \cdot$ Sven Mutke ${ }^{3,4}$ (i)

1 Chair of Forest Growth, University of Freiburg, Tennenbacher Str 4, 79106 Freiburg i.B, Germany

2 USDA, Forest Service, Southern Research Station, 1710 Research Center Drive, Blacksburg, VA, USA

3 INIA Forest Research Centre, Carretera de la Coruña km 7.5, 28040 Madrid, Spain

4 iuFOR, Sustainable Forest Management Research Institute, University of Valladolid \& INIA, 34004 Palencia, Spain

5 University School of Environment Management, Guru Gobind Singh Indraprastha University, New Delhi, India
6 Department of Plant and Soil Sciences, 5-15 Plant Sciences Complex, University of Pretoria, 5-15 Plant Sciences Complex, Hatfield, Pretoria 0028, South Africa

7 Federal Scientific Center of the East Asia Terrestrial Biodiversity, Vladivostok, Russia 690022

8 Forestry Research Institute of Malawi, Kufa Road, P.O. Box 270, Zomba, Malawi

9 School of Forestry, Northeast Forestry University, Harbin 150040, China

10 EEFRI, Ethiopian Environment and Forest Research Institute, Addis Ababa, Ethiopia 